\title{
原著：
}

\section{Evaluation of Usefulness of MRI Short Inversion Time Inversion Recovery Sequences in Routine Examination for Gynecologic Tumors : Comparison with T1- and T2- Weighted Spin Echo}

\author{
Satoru TAKEUCHI* and Miho SENUMA*
}

OBJECTIVE : The Short Inversion Time Inversion Recovery (STIR) is a magnetic resonance imaging (MRI) technique that minimizes fat signals and produces images different from those obtained by $\mathrm{T} 1-$ and $\mathrm{T} 2$ - weighted spin echo (SE). In imaging of gynecologic tumors, T1- and T2- weighted SE sequences have been routinely used. However, the usefulness of STIR in routine MRI examinations for detecting gynecologic tumors has not been reported. So we studied the STIR images in comparison with T1and T2- weighted SE images.

METHODS: One hundred twenty-one patients with uterine tumors, normal uterus and ovarian tumors who were examined with T1- and T2- weighted SE and STIR between December 1997 and October 1998 were enrolled as subjects. Results of MRI using both techniques were evaluated and images were graded CLEAR, SLIGHTLY CLEAR and UNCLEAR.

RESULTS : As for boundaries between the uterus with uterine tumors, normal uterus, and the pelvic organs, CLEAR accounted for $68.7 \%$ of the images on T1weighted SE, $42.2 \%$ on T2- weighted SE and $74.7 \%$ on STIR. There were significant differences between T2- weighted SE, and T1- weighted SE $(\mathrm{P}<.0001)$ and STIR $(\mathrm{P}$ $<.0001)$.

In identification of the inner structure of the uterine tumors, CLEAR was $6.3 \%$ on T1-weighted SE, 82.5\% on T2- weighted SE and $82.5 \%$ on STIR. There was no significant difference between T2- weighted SE and STIR. In identification of the inner structure of the tumors, the cases, one is CLEAR and the other is UNCLEAR, are 7 (T2weighted SE, CLEAR) and 6 (STIR, CLEAR) (total 13) in uterine tumors and 3 (T2weighted SE, CLEAR) in ovarian tumors.

CONCLUSION : STIR imaging should be used more in a routine MRI examination for gynecologic tumors in addition to ordinary spin echo sequences for T1- and T2weighted images.

(1)STIR (2)MRI (3)gynecologic tumor

†783-0004 1571 Oosone Ko, Nankoku, Kochi

* Department of Obstetrics and Gynecology, Kochi Nokyo General Hospital

(受付：1999年12月22日) 


\section{INTRODUCTION}

MRI sequences differentiate pelvic organs clearly, and therefore have been used to diagnose several gynecologic disorders. In general, T1- and T2- weighted spin echo (SE) techniques have been applied to the diagnosis of gynecologic tumors. More recently, fast spin echo has replaced conventional spin echo sequences in many places.

The short inversion time inversion recovery (STIR) method was reported in 1985 by Bydder $^{1)}$. The STIR sequence suppresses fat signals to set inversion time (TI) to a null point of fat tissue so that it can avoid the effect of intestinal movements and reduce artifact $^{2}$. Furthermore, the STIR sequence is very sensitive to pathological lesions, because of the high signal intensity of lesions with long $\mathrm{T} 1$ and $\mathrm{T} 2$ relaxation times and a simultaneous suppression of the interfering high signal of fatty tissue ${ }^{3 \sim 6)}$.

Despite some limitations, STIR imaging is a useful noninvasive method for disease states $^{7}$. The STIR technique is not a new method and can be performed in any type of MRI, but it has not been used in a routine MRI examination for gynecologic tumors.

We investigated whether we can employ STIR sequences in a routine magnetic resonance imaging (MRI) examination, in addi- tion to ordinary spin echo sequences for T1and T2- weighted images.

\section{MATERIALS AND METHODS}

\section{Patient population}

One hundred twenty-one consecutive patients with uterine tumors, normal uterus, and ovarian tumors who were examined by MRI between December 1997 and October 1998 were enrolled as subjects.

The subjects consisted of 63 with uterine tumors, 20 normal uterus and 38 ovarian tumors with ages ranging from 30 to 81,25 to 85 and 17 to 81 years, and an average age of $46.4 \pm 7.7,49.8 \pm 17.6$ and $47.9 \pm 17.4$ years, respectively (Table 1 ).

For evaluation, the clearness of the boundaries between the uterus with uterine tumors or normal uterus, ovarian tumors, and the pelvic organs was classified into three grades as CLEAR (2 points), SLIGHTLY CLEAR (1 point) and UNCLEAR (0 point). CLEAR was defined that more than $90 \%$ of the boundary was clear, SLIGHTLY CLEAR form $50 \%$ to $90 \%$ and UNCLEAR less tha $50 \%$. Similarly, identification of the inner structure of the uterine or ovarian tumors were classified as CLEAR, SLIGHTLY CLEAR and UNCLEAR. CLEAR was defined that almost all of the tumor structures were identified, SLIGHTLY CLEAR defined that

Table 1 Diagnosis and Number of Cases

\begin{tabular}{c|l|c}
\hline & \multicolumn{1}{|c|}{ diagnosis } & number of cases \\
\hline \multirow{2}{*}{ uterus } & leiomyoma & 44 \\
& adenomyosis & 15 \\
& endometrial polyp & 3 \\
& leiomyosarcoma & 1 \\
& normal uterus & 20 \\
\hline \multirow{2}{*}{ ovary } & benign ovarian tumor & 35 \\
& ovarian cancer & 3 \\
\hline total & & 121 \\
\hline
\end{tabular}


some parts of the tumor structures were identified an UNCLEAR defined that almost all of the tumor structures were not identified.

\section{MR technique}

A MRP-20EX Scan (0.2T; Hitachi, Tokyo, Japan) was used and T1- weighted SE (TR/ TE : 650/25), T2- weighted SE (TR/TE : 5000/ 120), and STIR (TR/TE/TI : 2000/38/90) pulse sequences were employed. A body coil was used for imaging. The matrix size was $256 \times$ 256 , and the slice thickness was $10 \mathrm{~mm}$ with $0.5 \mathrm{~mm}$ slice gap.

\section{Image analysis}

MR images were evaluated on sagital plane in the uterine tumors and uterus, and on transverse plane in the ovarian tumors.

All MR images were interpreted twice independently on different days by one gynecologist (author) who had no knowledge of the patients' clinical history, and/or pathological data. The Wilcoxon signed rank test was em- ployed to determine the differences between T1-, T2- weighted SE and STIR images. Statistically significant differences were indicated with $\mathrm{P}<.05$.

\section{RESULTS}

As for boundaries between the uterus with uterine tumors, normal uterus, and the pelvic organs, CLEAR was $68.7 \%$ on $\mathrm{T} 1$ - weighted SE, $42.2 \%$ on T2- weighted SE and $74.7 \%$ on STIR. There were significant differences between T2- weighted SE, and T1- weighted $\mathrm{SE}(\mathrm{P}<.0001)$ and STIR $(\mathrm{P}<.0001)$ (Fig. 1). In identification of the inner structure of the uterine tumors, CLEAR was $6.3 \%$ on T1weighted SE, $82.5 \%$ on T2- weighted SE and $82.5 \%$ on STIR. There was no significant difference between T2- weighted SE and STIR (Fig. 2).

In boundaries between the ovarian tumors and the pelvic organs, CLEAR was $52.6 \%$, $60.5 \%$ and $60.5 \%$ each on $\mathrm{T} 1-$, T2- weighted SE and STIR (Fig. 3). In identification of the

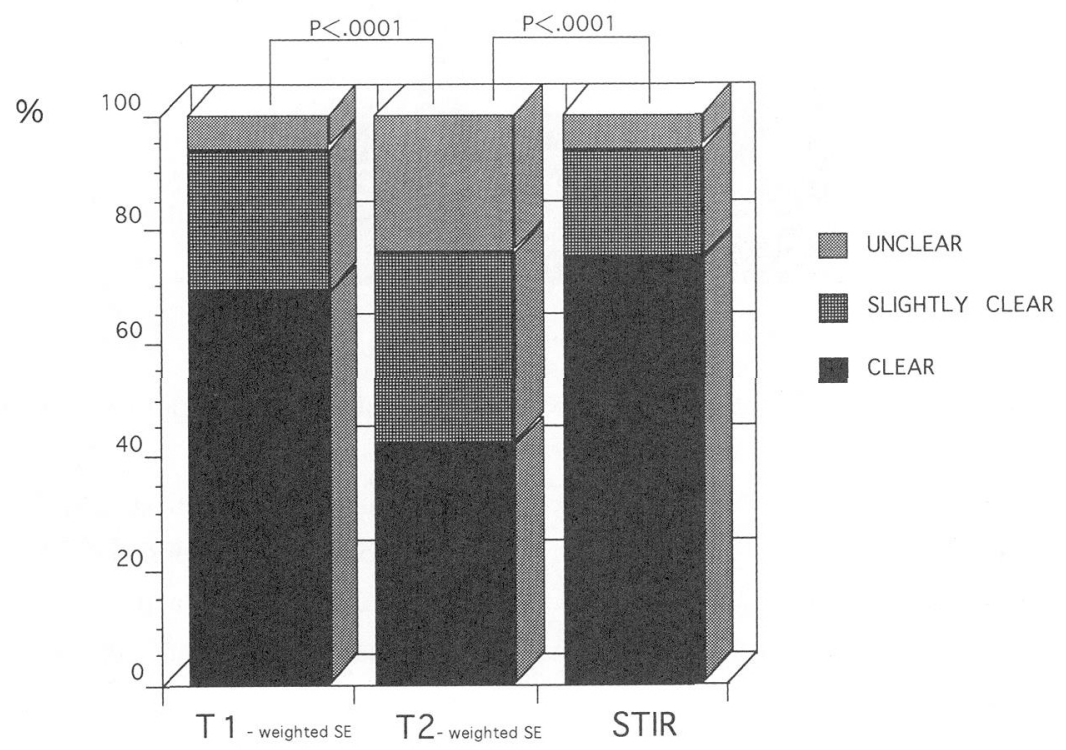

Fig. 1 Grades of boundaries between uterus with uterine tumors and normal uterus, and pelvic organs 


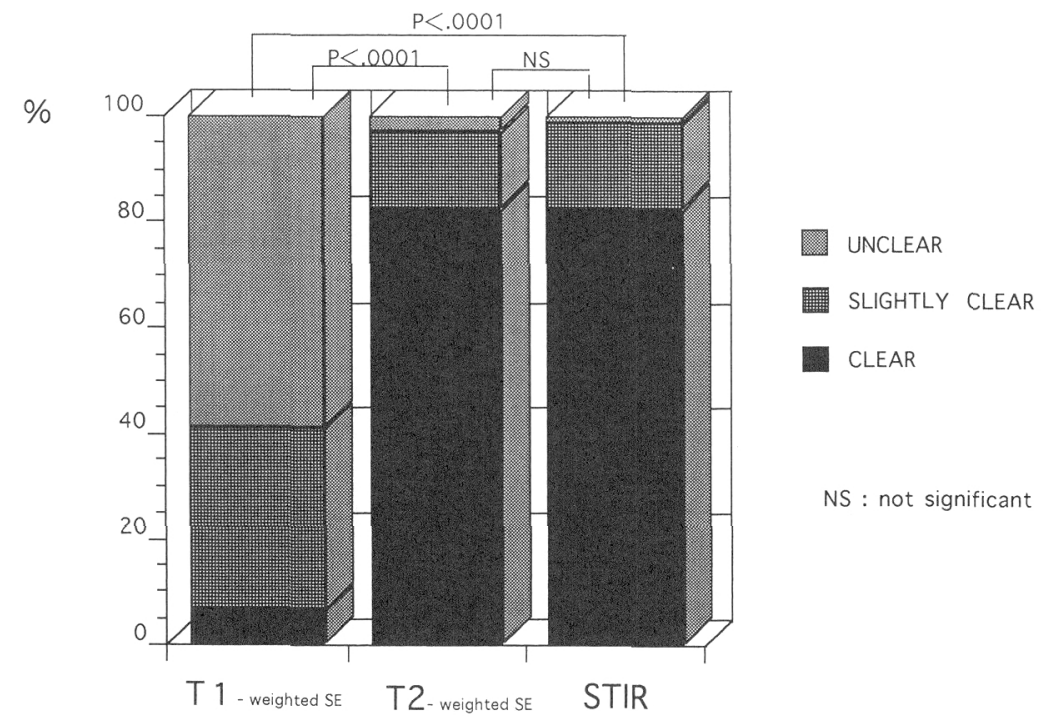

Fig. 2 Grades of identification of inner structure of uterine tumors

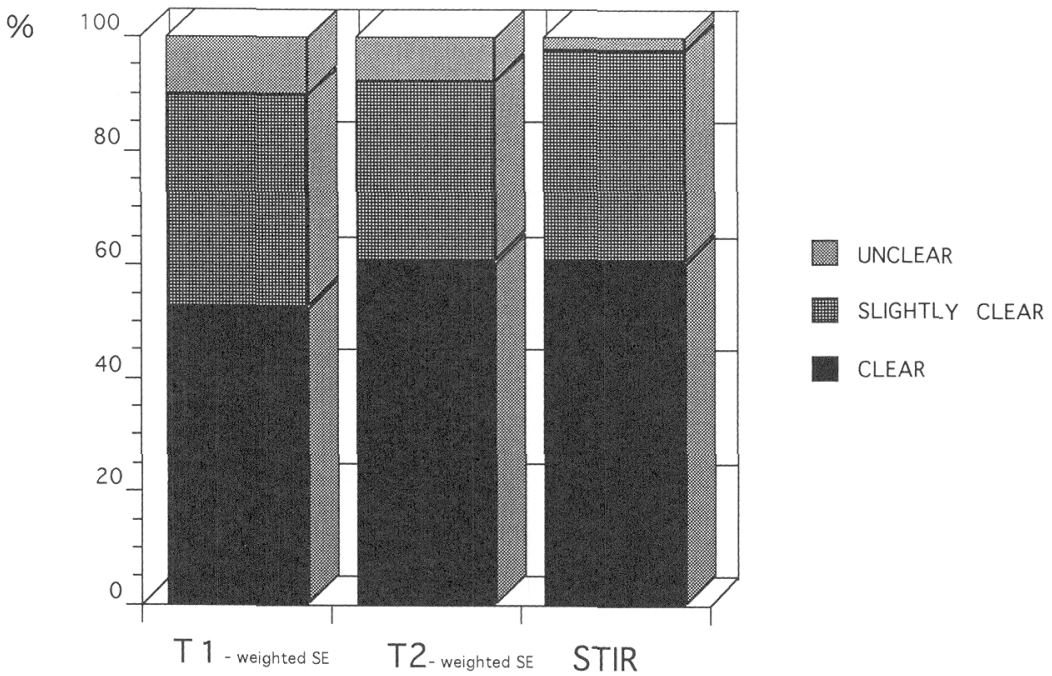

Fig. 3 Grades of boundaries between ovarian tumors and pelvic organs

inner structure of the ovarian tumors, CLEAR was $71.1 \%, 84.2 \%$ and $78.9 \%$ each on T1-, T2- weighted SE and STIR (Fig. 4). There were no significant differences in boundaries between the ovarian tumors and the pelvic organs, and identification of the inner structures of the ovarian tumors.

The ratio of consistence between the first and second evaluated results in each patient was $86.8 \%$ on T1-weighted SE and $90.4 \%$ on STIR between the uterus with uterine tumors or normal uterus, and the pelvic organs, and $88.9 \%$ on $\mathrm{T} 2$ - weighted $\mathrm{SE}$ and $82.5 \%$ on STIR in identification of the inner structure of the uterine tumors. 
$\%$

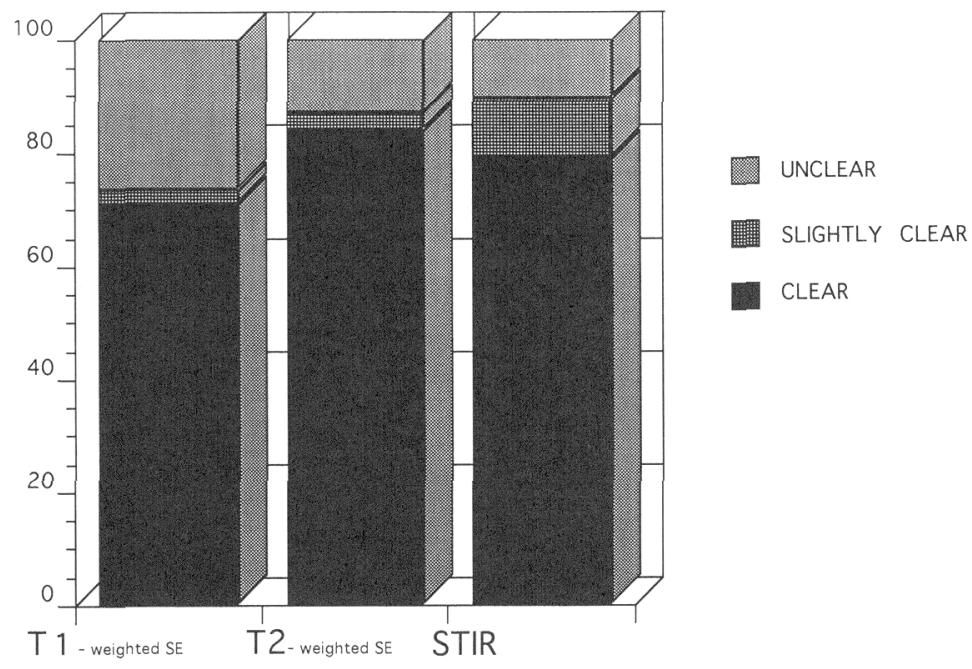

Fig. 4 Grades of identification of inner structure of ovarian tumors

\section{DISCUSSION}

It has been known that the benefit of STIR is : 1. suppression of fat signals so that it can avoid the effect of intestinal movements 2 . benefits of both T1- and T2- weighted SE for rather long echo time (TE) 3. decreased chemical shift artifact $(\mathrm{CSA})^{8)}$. Furthermore, in STIR sequences the increase in both the $\mathrm{T} 1$ and the $\mathrm{T} 2$ relaxation times of most pathologic abnormalities is used to produce increased signal intensity ${ }^{9}$. Therefore, STIR images usually provide optimal contrast for lesion detection ${ }^{9}$. Fat suppression with STIR sequences is based on short $\mathrm{T} 1$ relaxation rates and therefore is not tissue-specific ${ }^{10}$. The signal from any tissue with a short $\mathrm{T} 1$, similar to that of fat, may be nulled as well ${ }^{10}$. So STIR pulse sequences are quite different from the frequency-selective fat suppression technique, in which the signal from fat protons is selectively nulled on the basis of the intrinsic chemical shift differences between lipid and water protons ${ }^{10)}$. Although a frequency-selective fat suppression technique can be used only in several specified MRI ${ }^{11 \sim 13)}$,
STIR can be utilized in ordinary MRI machines.

Major disadvantages of the STIR sequence is low signal-to-noise ratios and the long scanning time because of the long repetition time $(\mathrm{TR})^{2,14}$. Turbo STIR can shorten the time, but it can be also used in several specified MRI ${ }^{9)}$. It has been reported that the STIR technique is used in the diagnosis of gynecologic tumors. An ovarian chocolate cyst was diagnosed when a T1- elongated lesion showed shading, loculus, or a low intensity rim on SE MR images, and a low intensity rim on STIR-MRI ${ }^{8}$. Findings of STIR images of parametrium invasion in cancer of the uterine cervix and myometrial invasion in cancer of the uterine corpus had been reported. Scheidler et al said that no statistically significant differences were found between staging with T2- weighted turbo SE, turbo STIR, and T1- weighted fat-suppressed gadolinium-enhanced SE images ${ }^{15}$. However, imaging with excitation-spoiling fat suppression combined with contrast material enhancement and fat suppression with a 
short inversion time inversion recovery (STIR) sequence has been shown to improve lesion characterization and tumor staging in MR imaging of ovarian, bladder, and colorectal cancer ${ }^{16-19)}$. Detection of lymph node metastasis in ovarian carcinoma and uterine corpus carcinoma by preoperative CT or MRI has been reported ${ }^{20)}$. The results of MRI indicated that the T1- weighted image and STIR image were the most accurate in identifying metastatic lymph nodes ${ }^{20)}$. In our cases of ovarian cancer, lymph node metastasis had not been found.

Thus, STIR sequences had been utilized in definite conditions, although it has not been reported that the STIR sequence is useful in a routine examination for gynecologic tumors.

In general, it has been known that T2weighted SE could precisely depict the intrauterine tumor, although sometimes not precisely do the boundary of the uterus. In our cases, clearness between the boundaries of the uterus with uterine tumors and normal uterus, and the pelvic organs is significantly better on STIR $(\mathrm{P}<.0001)$ and $\mathrm{T} 1-$ weighted $\mathrm{SE}(\mathrm{P}<.0001)$ than $\mathrm{T} 2-$ weighted SE (Fig. 1). Although there is no statistical difference be-

Table 2 Observed frequencies for grades of boundaries between uterus with uterine tumor and normal uterus, and pelvic organs on T1- weighted SE and STIR

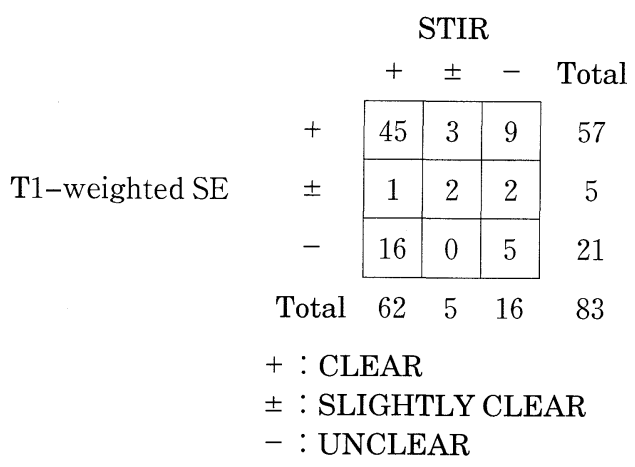

tween that of ovarian tumors and the pelvic organs between MR images of T1-, T2weighted SE and STIR (Fig. 3). The inner structure of the uterine tumors were clearly identified on STIR $(\mathrm{P}<.0001)$ and T2weighted SE $(\mathrm{P}<.0001)$, compared with $\mathrm{T} 1-$ weighted SE (Fig. 2). The clearness in that of ovarian tumors were the same on T1-, T2weighted SE and STIR (Fig. 4).

The ratio of CLEAR of the boundaries from the pelvic organs was $68.7 \%$ on T1- weighted SE and $74.7 \%$ on STIR each in uterine tumor or normal uterus, and $52.6 \%$ on T1- weighted SE and $60.5 \%$ on STIR each in ovarian tumor.

That seemed almost the same between T1weighted SE and STIR about CLEAR of the boundaries. Although the cases, one is CLEAR and the other is UNCLEAR, are 9 (T1- weighted SE, CLEAR) and 16 (STIR, CLEAR) (total 25) in uterus with uterine tumor and normal uterus, and 7 (T1- weighted SE, CLEAR) and 8 (STIR, CLEAR) (total 15) in ovarian tumor (Tables 2 and 3).

That suggests that the combination of T1weighted SE and STIR in the boundaries between the uterus or ovarian tumors, and pelvic organs is useful.

Table 3 Observed frequencies for grades of boundaries between ovarian tumor and pelvic organs on T1-weighted SE and STIR

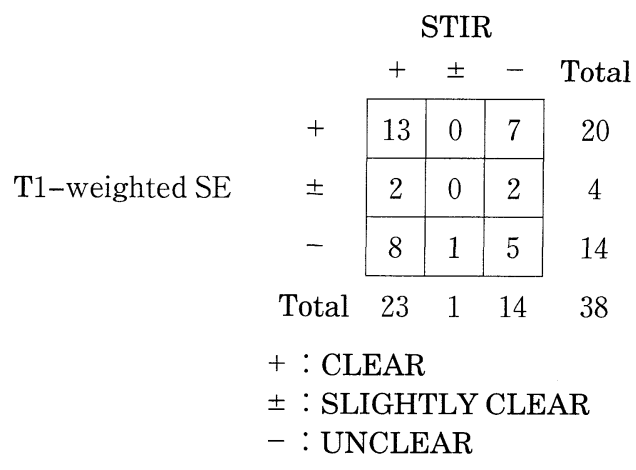


Also, the ratio of CLEAR of identification of the inner structure of the tumors was $82.5 \%$ on T2- weighted SE and $82.5 \%$ on STIR each in uterine tumors, and $84.2 \%$ on $\mathrm{T} 2-$ weighted SE and $78.9 \%$ on STIR each in ovarian tumors. The cases, one is CLEAR and the other is UNCLEAR, are 7 (T2- weighted SE, CLEAR) and 6 (STIR, CLEAR) (total 13) in uterine tumors and 3 (T2-weighted SE, CLEAR) in ovarian tumors (Tables 4 and 5).

The combination of T2- weighted SE and

Table 4 Observed frequencies for grades of identification of inner structure of uterine tumor on $\mathrm{T} 2-$ weighted SE and STIR

\begin{tabular}{|c|c|c|c|c|c|}
\hline & & & STI & & \\
\hline & & + & \pm & - & Total \\
\hline & + & 45 & 0 & 7 & 57 \\
\hline $\mathrm{T} 1$-weighted SE & \pm & 1 & 1 & 0 & 2 \\
\hline & - & 6 & 0 & 3 & 9 \\
\hline & Total & 52 & 1 & 10 & 63 \\
\hline & $\begin{array}{l}+: \mathrm{CL} \\
\pm: \mathrm{SL} \\
-\end{array}$ & $\begin{array}{l}\text { EAH } \\
\text { IGH }\end{array}$ & & & \\
\hline
\end{tabular}

STIR in identification of the inner structure of the uterine tumors is more useful than that of ovarian tumors. A STIR image in our cases of myoma is shown in Fig. 5 which shows a benefit of both T1- and T2- weighted SE. MR images of the ovarian cyst are shown in Fig. 6.

In conclusion, STIR imaging should be used in a routine MRI examination for gynecologic tumors in addition to T1- and T2- weighted SE.

Table 5 Observed frequencies for grades of identification of inner structure of ovarian tumor on $\mathrm{T} 2-$ weighted SE and STIR

\begin{tabular}{|c|c|c|c|c|c|}
\hline & \multicolumn{5}{|c|}{ STIR } \\
\hline & & + & \pm & - & Total \\
\hline & + & 29 & 0 & 3 & 32 \\
\hline T1-weighted SE & \pm & 1 & 3 & 1 & 5 \\
\hline & - & 0 & 1 & 0 & 1 \\
\hline & Total & 30 & 4 & 4 & 38 \\
\hline & $\begin{array}{l}+: \mathrm{CL} \\
\pm: \mathrm{SL} \\
-: \mathrm{UN}\end{array}$ & $\begin{array}{l}\text { EAR } \\
\text { GH } \\
\text { CLF }\end{array}$ & & & \\
\hline
\end{tabular}

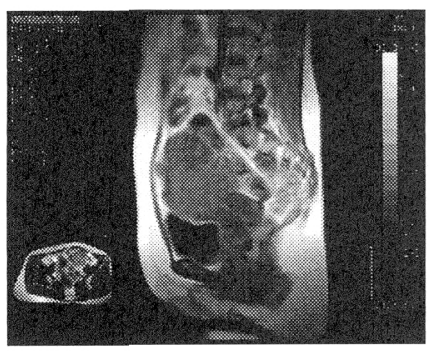

A

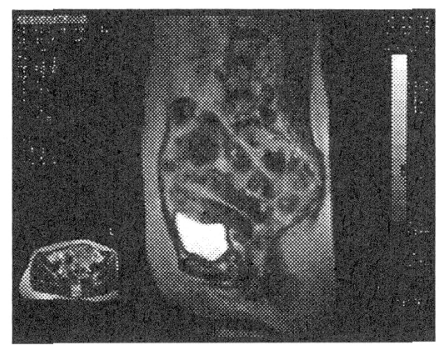

B

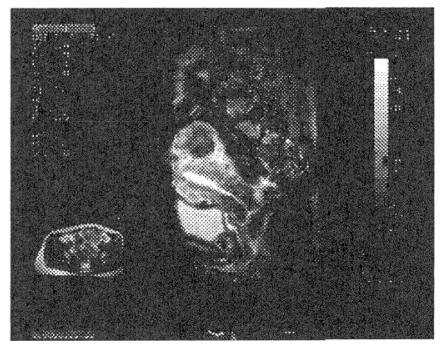

C

Fig. 5 Images of uterine myoma

A : T1-weighted SE Boundary between the uterus and pelvic organs is SLIGHTLY CLEAR. Identification of the inner structure of the myoma node is SLIGHTLY CLEAR.

B : T2- weighted SE Boundary between them is UNCLEAR. Identification of it is CLEAR.

$\mathrm{C}$ : STIR Boundary between them is CLEAR. Identification of it is CLEAR. 


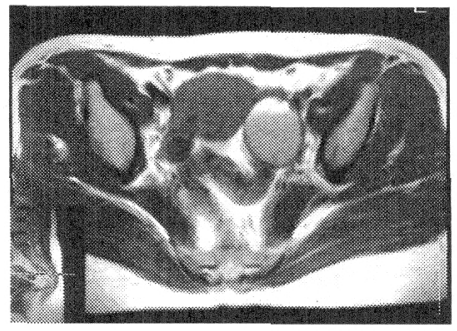

A

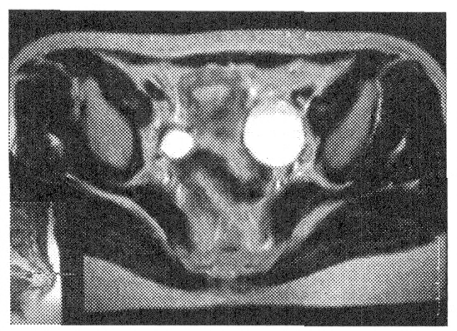

B

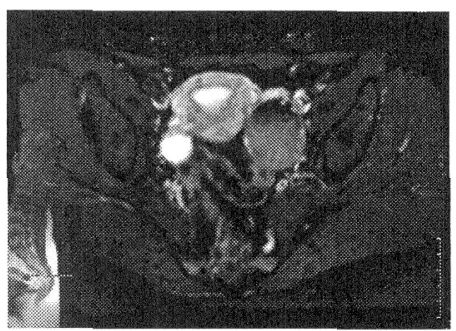

C

Fig. 6 Images of the left ovarian dermoid cyst

A : T1- weighted SE Boundary between the uterus and pelvic organs is CLEAR. Identification of the inner structure of the myoma node is CLEAR.

B : T2- weighted SE Boundary between them is CLEAR. Identification of it is CLEAR.

$\mathrm{C}: \mathrm{STIR}$

Boundary between them is CLEAR. Identification of it is CLEAR.

\section{REFERENCES}

1) Bydder GM, Young IR. MR imaging; Clinical use of the inversion recovery sequence. J Comput Assist Tomogr $1985 ; 9: 659-675$.

2 ) Hittmair K, Tratting S, Herold CJ, Breitenseher M, Kramer J. Comparison between conventional and fast spin-echo STIR sequences. Acta Radiologica $1996 ; 37: 943-949$.

3 ) Baker LL, Goodman SB, Perkash I, Lane B, Enzmann DR. Benign versus pathologic compression fractures of vertebral bodies. Assessment with conventional spin-echo, chemical-shift, and STIR MR imaging. Radiology $1990 ; 174: 495$ 502.

4) Bartolozzi C, Caramella D, Zampa V, et al. MR imaging with STIR technique and air insufflation for local staging of bladder neoplasms. Acta Radiol $1992 ; 33$ : 577-581.

5 ) Dwyer AJ, Frank JA, Sank VJ, Reinin JW, Hickey AM, Doppman JL. Short-TI inversion-recovery pulse sequences. Analysis and initial experience in cancer imaging. Radiology 1988; 168: 827-836.

6 ) Stimac GK, Porter BA, Olson DA, Berlach R, Genton M. Gadolinium-DTPA-enhanced MR imaging of spinal neoplasms. Preliminary investigation and comparison with spin-echo and STIR sequences. AJNR 1988; $9: 839-846$.

7) Mori M, Fukuda T, Nagayoshi K, et al. Insulinoma : correlation of short-TI inversion-recovery (STIR) imaging and histopathologic findings. Ab- dom Imaging $1996 ; 21: 337-341$.

8 ) Kaori K. Detection and characterization with short TI inversion recovery MR imaging. Journal of Nippon Medical School 1994; 61 : 372-388.

9 ) Smith RC, Constable RT, Reinhold C, McCauley T, Lange RC, McCarthy S. Fast spin echo STIR imaging. J Comput Assist Tomogr 1994 ; 18 : 209 213.

10) Krinsky G, Rofsky NM, Weinreb JC. Nonspecificity of short inversioin time inversion recovery (STIR) as a technique of fat suppression : Pitfalls in image interpretation. Am J Roentogenol 1996; $166: 523-526$.

11) Takahashi K, Okada S, Kitao M, Sugimura K. Magnetic resonance imaging using "fat-saturation" technique is useful for diagnosing small endometrioma; A case report. Fertil Steril 1992; $58: 1063-1064$.

12) Sugimura K, Okizuka $H$, Imaoka I, et al. Pelvic endometriosis; Detection and diagnosis with chemical-shift MR imaging. Radiology 1993; $188: 435-438$.

13) Kier R, Smith RC, McCarthy SM. Value of lipidand water-suppression MR images in distinguishing between blood and lipid within ovarian masses. Am J Roentogenol $1992 ; 158$ : 321-325.

14) Shuman WP, Baron RL, Peters MJ, Tazioli PK. Comparison of STIR and spin-echo MR imaging at $1.5 \mathrm{~T}$ in 90 lesions of the chest, liver, and pelvis. Am J Roentogenol 1989; 152: 853-859.

15) Juergen S, Andreas FH, Marc S, Rainer K, Maximilian FR. Parametrial invasion in cervical carci- 
noma : Evaluation of detection at MR imagingwith fat suppression. Radiology 1998 ; 206 : 125129.

16) Semelka RC, Lawrence PH, Shoenut JP, Heywood M, Kroeker MA, Lotocki R. Primary ovarian cancer : Prospective comparison of contrast-enhanced CT and pre-and postcontrast, fat-suppressed MR imaging, with histologic correlation. Journal of MRI $1993 ; 3: 99-106$.

17) Okizuka H, Sugimura K, Yoshizako T, Kaji Y, Wada A. Rectal carcinoma : Prospective comparison of conventional and gadopentetate dimeglumine-enhanced fat-suppressed MR imaging. Journal of MRI $1996 ; 6: 465-471$.

18) Bartolozzi C, Caramella D, Zampa V, et al. MR imaging with STIR technique and air insufflation for local staging of bladder neoplasms. Acta Radiol $1992 ; 33: 577-581$.

19) Masuko E, Homma H, Mezawa S, Matsuyama T, Watanabe N, Niitsu Y. Determining depth of invasion of advanced colorectal cancer using MRI short inversion time inversion recovery sequences. Journal of gastroenterol $1996 ; 31: 361$ -365 .

20) Sugiyama T, Nishida T, Ushijima K, et al. Detection of lymph node metastasis in ovarian carcinoma and uterine corpus carcinoma by preoperative computerized tomography or magnetic resonance imaging. J Obstet Gynaecol.1995 ; $6: 551$ $-556$.

\title{
婦人科腫瘍 MRI 検查における STIR (Short Inversion Time Inversion Recovery）法の有用性についての検討
}

\author{
竹内 悟* · 瀬沼美保*
}

目的：MRI 撮影における STIR（Short Inversion Time Inversion Recovery）法は T 1 強調像， T 2 強調像とは異なった画像を得ることができ，またガドミニウム造影の様な侵 襲もない。しかし婦人科腫瘍の MRI 検査では $\mathrm{T} 1$ 強調像, $\mathrm{T} 2$ 強調像のみが撮影される 場合が多い。そこでSTIR 法の有用性について検討した。

対象：1997年12月から1998年10月までの間，121名の子宮腫瘍，正常子宮，卵巣腫瘍の ある患者が対象として検討された。MRI 画像の評価は, CLEAR, SLIGHTLY CLEAR, UNCLEARの 3 段階に分類した。

結果：子宮と骨盤内臓器の境界に関しては, CLEAR が $\mathrm{T} 1$ 強調像で $68.7 \%, \mathrm{~T} 2$ 強調 像で42.2\%, STIR 法で74.4\%であった。 T 2 強調像に比し T 1 強調像, STIR 法で有意に 明暸であったが, T 1 強調像, STIR 法の間に有意差は無かった。子宮腫瘍の内部構造に 関しては, CLEAR が T 1 強調像で6.3\%, T 2 強調像で $82.5 \%$, STIR 法で $82.5 \%$ あっ た。T 2 調強調像と STIR 法の間には差が無かった。腫瘍の内部構造に関して, 子宮腫痬 では T 2 強調像が CLEAR で且つSTIR 法が UNCLEAR が 7 例, T 2 強調像が UNCLEAR で且つ STIR 法が CLEAR が 6 例であり, 卵巣腫瘍では T 2 強調像が CLEAR で 且つSTIR 法が UNCLEAR が 3 例であった。

結論：STIR 法は T 2 強調像, T 1 強調像と共に撮影することは有用と考えられた。

\footnotetext{
* 高知県農協総合病院 産婦人科
} 